\title{
A Transition to Which Bioeconomy? An Exploration of Diverging Techno-Political Choices
}

\author{
Daniel Hausknost ${ }^{1,2, *}$, Ernst Schriefl ${ }^{3}$, Christian Lauk ${ }^{2}$ and Gerald Kalt ${ }^{4}$ \\ 1 Institute for Social Change and Sustainability (IGN), Vienna University of Economics and Business (WU), \\ Welthandelsplatz 2, 1020 Vienna, Austria \\ 2 Institute of Social Ecology Vienna (SEC), Alpen Adria Universitaet Klagenfurt, Schottenfeldgasse 29, \\ 1070 Vienna, Austria; christian.lauk@aau.at \\ 3 Energieautark Consulting gmbh, Viktor-Hagl-Gasse 16, 1140 Vienna, Austria; ernst.schriefl@energieautark.at \\ 4 Austrian Energy Agency, Mariahilfer Str. 136, 1150 Vienna, Austria; gerald.kalt@energyagency.at \\ * Correspondence: daniel.hausknost@wu.ac.at; Tel.: +43-1-31336-6045
}

Academic Editor: Helmut Haberl

Received: 7 March 2017; Accepted: 18 April 2017; Published: 23 April 2017

\begin{abstract}
To date the concept of the bioeconomy—an economy based primarily on biogenic instead of fossil resources-has largely been associated with visions of "green growth" and the advancement of biotechnology and has been framed from within an industrial perspective. However, there is no consensus as to what a bioeconomy should effectively look like, and what type of society it would sustain. In this paper, we identify different types of narratives constructed around this concept and carve out the techno-political implications they convey. We map these narratives on a two-dimensional option space, which allows for a rough classification of narratives and their related imaginaries into four paradigmatic quadrants. We draw the narratives from three different sources: (i) policy documents of national and supra-national authorities; (ii) stakeholder interviews; and (iii) scenarios built in a biophysical modelling exercise. Our analysis shows that there is a considerable gap between official policy papers and visions supported by stakeholders. At least in the case of Austria there is also a gap between the official strategies and the option space identified through biophysical modelling. These gaps testify to the highly political nature of the concept of the bioeconomy and the diverging visions of society arising from it.
\end{abstract}

Keywords: bioeconomy; transition; biotechnology; bio-resources; technopolitics; agro-ecology; sufficiency; capitalism

\section{Introduction}

With the climate challenge looming large and the depletion of fossil energy resources at the horizon; the vision of a bioeconomy - an economy based primarily on biogenic instead of fossil resources-has risen to political prominence in recent years. The European Union has become one of the most fervent proponents of the concept and with its "Low Carbon Roadmap" [1] and the "Bioeconomy Strategy" [2] has committed itself to establishing a bioeconomy until 2050.

To date the concept has largely been associated with visions of "green growth" and the advancement of agricultural and industrial biotechnologies and has been framed from within an industrial perspective. However, there is no consensus as to what a bioeconomy could or should effectively look like and what type of society it would sustain. While there are some emergent alternative visions, which focus on small-scale and organic agriculture and include a sufficiency perspective that requires absolute reductions of consumption levels [3,4], they are politically marginalised [5]. However, there may be many more options than a binary juxtaposition of these two poles. This paper aims to explore the techno-political option space the concept of a bioeconomy 
offers and to identify clusters of narratives of the bioeconomy with their respective socio-economic, biophysical and political implications. We start from the assumption that a transition to a bioeconomy can take many forms and lead to many different types of societies. Consequently, the objective to engage in a transition to a low-carbon bioeconomy is fraught with diverging techno-political choices based on conflicting or even incompatible visions. Either these choices can remain invisible to the wider public and marginalised by hegemonic discourses and interests, or they can become subject to democratic deliberations, contestations and decision-making. In this paper, we take the normative position that it is important to make the choices involved in the concept of a bioeconomy visible and subject to open and democratic contestation.

Methodologically, we employ concepts from discourse analysis and science and technology studies (STS) that have fruitfully been applied to the study of the bioeconomy in the past. In doing so, we build on work by Levidow et al. [4] and Hecht [6]. We follow their approach in conceptualising the techno-political choices as technosocial "narratives", and the societal visions they convey as "imaginaries". Originally coined by François Lyotard, the term (master-)narrative in STS refers to "the cultural vehicles through which ideas of progress are linked to S\&T in particular ways. These are not 'merely' stories or fictions. They are an important part of the cultural and institutional fabric, of taken-for-granted aspects of social order" ([7], p. 12). Such narratives constitute frames through which societal problems and their solutions are constructed in a mutually constitutive way, that is, within a given narrative "the putative technoscientific solutions pre-define the problems to be solved" ([4], p. 42).

Narratives are "founded in collective imaginations and associated material objects and institutional practices, together constituting what social scientists sometimes refer to as imaginaries" ([7], p. 73). Imaginaries, as defined in critical discourse analysis, "pre-figure a possible and intended reality, which includes an objective and a strategy to achieve it" ([4], p. 42). They convey visions of how things might or could or should be, and as such, according to Fairclough (2010), they "are an integral part of strategies; and if strategies are successful and become implemented, then associated imaginaries can become operationalized, transformed into practice, made real" ([8], cited in [4], p. 42). According to Gabrielle Hecht, the term technopolitics "describes the strategic practice of designing or using technology to constitute, embody, or enact political goals" ([6], p. 56). We loosely draw on this definition in order to express our view that technological choices are always deeply embedded in political visions of society and in pre-existing networks of institutions, actors, interests and ideologies, which Hecht calls technopolitical regimes (ibid.). The diverging visions of the bioeconomy therefore epitomise different technopolitical strategies to promote and ultimately realise potentially very different types of society.

With this paper, we aim to add to a developing body of literature-prominently in this journal - that is concerned with understanding the societal meaning and consequences of the concept of the bioeconomy, e.g., [3,9-15]). We identify different types of narratives constructed around the concept of the bioeconomy and carve out the specific visions of societal development they convey. We map these narratives on a two-dimensional "techno-political option space", which allows for a rough classification of narratives into four quadrants representing societal master-narratives (Sustainable Capital; Eco-Growth; Eco-Retreat; and Planned Transition). In doing so, we arrive at a typology that is organised along broad techno-political visions rather than narrowly defined socio-technical criteria $[10,16]$. We draw the narratives from three different sources: (i) policy documents from national and supra-national authorities; (ii) stakeholder interviews; and (iii) scenarios built in a biophysical modelling exercise. The aim is to compare and contrast "official" elite-driven narratives with those of other stakeholders in academia, industry, agriculture and civil society and with narratives that are scientifically constructed in complex system modelling based on biophysical data. The result is a map that reveals clusters of imaginaries and the gaps between them and that may help opening up the debate about the various techno-political choices involved in a transition to a bioeconomy. 
We then confront the techno-political narratives derived through the application of discourse-analytical methods with biophysical scenarios derived from a complex system modelling exercise. This combination of very different methods to conceptualize and assess narratives and scenarios, respectively, helps us to 'ground' the techno-political narratives in biophysical reality. Thus, we can start to assess and discuss to what extent the narratives and visions present in the techno-political options-space of society are consistent with the biophysical option-space of society. In conclusion, we discuss the resulting techno-political options and their implications for both politics and future research.

\section{Diverging Visions of the Bioeconomy}

While conceptions of a bioeconomy can be traced back to the 1990s [17], the concept gained political salience after the year 2000. On the most general level, a bioeconomy "can be understood as an economy where the basic building blocks for materials, chemicals and energy are derived from renewable biological resources, such as plant and animal sources" ([18], p. 2590). Within this broad understanding, several diverging visions of the bioeconomy have emerged. In the academic literature, some attempts have been made to identify different uses of the bioeconomy concept. Staffas et al. [15], for example, distinguish between the 'bioeconomy' (BE) and the 'bio-based economy' (BBE). The term BE is being used predominantly by the OECD, who defined it as "transforming life science knowledge into new, sustainable, eco-efficient and competitive products" ([19], p. 326, cited in [15], p. 2755). Thus, "[t]he concept of the BE is focused on the methods of conversion of raw material into value added products" ([15], p. 2755), and in particular on biotechnology as a conversion technology. By contrast, the European Union (EU) uses the term BBE, which, according to the authors, "focuses on the raw material rather than the conversion process" ([15], p. 2756). In a document from 2011, for example, the European Commission (EC) states that "a bio-based economy integrates the full range of natural and renewable biological resources-land and sea resources, biodiversity and biological materials (plant, animal and microbial), through to the processing and the consumption of these bio-resources" ([20], p. 9). While the BE concept is thus technology-driven, the BBE-concept is resource-driven in that it foregrounds the task of a transition from a fossil-based to a bio-based economic system. Within the BBE concept, Levidow et al. [4,12] identified two contending visions-one (again) biotechnology-oriented, the other agro-ecology oriented. The biotech-vision is influenced by the OECD conception of the bioeconomy and is politically dominant, whereas the agro-ecological vision is influenced by organic farming and alternative visions of the food and energy system and is, unsurprisingly, politically marginalised.

We can thus distinguish—very much in line with recent findings by Bugge et al. [10]—-three broad types of narratives: a biotechnology-centred one; a bio-resource-centred one and an agro-ecological one. The biotechnology-centred vision of the bioeconomy was the first to emerge and closely tied to the agenda of the life sciences and biotech industry $[12,18]$. Only later were environmental objectives included-in particular climate change mitigation and the transition to a sustainable post-fossil society - and the focus of the narrative shifted somewhat toward an economy based on renewable biomass and "green growth".

In the EU, the search for a new economic paradigm after a phase of stagnation led to the call for a knowledge-based economy (KBE) in the 2000 Lisbon Agenda [21], which was soon extended to become the 'knowledge-based bio-economy' (KBBE) [22,23]. This extension testifies to the European Commission (EC)'s belief that the life sciences and biotechnology are "probably the most promising of the frontier technologies" to further the Lisbon Agenda's objective of making Europe the leading knowledge-based economy ([22], p. 8). This technology-driven perspective changed slightly into a purpose-driven one when, in the first decade of the new millennium, the climate discourse gained unprecedented urgency, as marked by the publication of the Stern Review in 2006 [24] and the 2007 IPCC Fourth Assessment Report [25]. The EU responded to the climate challenge in a number of strategy documents, including the 20-20-20 climate goals established in 2008 [26], the EU 2020 strategy 
from 2010 [27] and the resource efficiency platform established in 2011 [28]. In 2012, the EC launched a new bioeconomy strategy, which explicitly builds on these policy documents. This strategy document, entitled "Innovating for Sustainable Growth: A Bioeconomy for Europe" [2], starts by proclaiming that:

"In order to cope with an increasing global population, rapid depletion of many resources, increasing environmental pressures and climate change, Europe needs to radically change its approach to production, consumption, processing, storage, recycling and disposal of biological resources. [ ... ] Establishing a bioeconomy in Europe holds a great potential: it can maintain and create economic growth and jobs in rural, coastal and industrial areas, reduce fossil fuel dependence and improve the economic and environmental sustainability of primary production and processing industries" ([2], p. 2).

Within this strategy, the bioeconomy is defined to encompass "the production of renewable biological resources and the conversion of these resources and waste streams into value added products, such as food, feed, bio-based products and bioenergy". This definition emphasises the strategy's focus on renewable resources, circular economic processes and bioenergy, while it leaves open the role of biotechnology. In this respect, the EU narrative diverges considerably from that of the OECD, whose strategy document "The Bioeconomy to 2030: Designing a Policy Agenda" from 2009 [19], is almost entirely dedicated to the political advancement of biotechnology. It reveals this ambition when it states that ' $[\mathrm{b}]$ iotechnology offers technological solutions for many of the health and resource based challenges facing the world. [ ... ] Yet [it] is unlikely to fulfil its potential without appropriate regional, national and, in some cases, global policies to support its development and application" ([19], p. 8).

It should be noted, however, that the EU strategy does not discard its original focus on biotechnology, which is well in accordance with the OECD agenda. Instead, it changed the framing of the bioeconomy's main purpose toward an overarching post-fossilistic sustainability agenda, within which biotechnology still has an important—albeit less talked about—role. Indeed, as several studies stress, the EU's research programme for a bioeconomy is dominated by a life sciences vision, which is exemplified by the dominance of the biotechnological research agenda in the Seventh Framework Programme (FP7) and its successor, Horizon 2020 [12,14,29]. Crucially, both the EU and OECD strategies regard the bioeconomy primarily as a chance to engender new and sustained economic growth and enhance competitiveness in a globalised economy. For the EU, the bioeconomy is "a key element for smart and green growth in Europe" ([2], p. 2), whereas the OECD, in a document from 2006, describes the bioeconomy as "the aggregate set of economic operations in a society that use latent value incumbent in biological products and processes to capture new growth and welfare benefits for citizens and nations" ([30], p. 3).

In addition, and partly in reaction, to the dominant biotechnology- and agroindustry-oriented visions of the bioeconomy, the contours of a third type of vision is emerging. This vision is oriented toward agro-ecological practices and a more comprehensive understanding of societal sustainability. Originating from civil society networks, organic farming organisations and critical academia, this alternative narrative (or set of narratives) articulates organic farming practices and technologies with socio-political visions of "food sovereignty", participatory governance and a sufficiency perspective that rejects economic growth as an end in itself [4,12,31-33]. In an attempt to influence the European research agenda on the bioeconomy and to get a foothold in the associated research funds, the European organics industry established a "Technology Platform for Sustainable Organic and High Welfare Food and Farming Systems (TP Organics)", which is now one of the 40 European Technology Platforms (ETPs) officially recognized by the European Commission. Its main function is to identify the research needs of the organic sector and agro-ecological farmers and to relay research priorities to the policy-makers. In its vision, TP Organics portrayed organic food and farming systems as "an important and fast-growing part of the European knowledge-based bio-economy" [34] and devised a research agenda based on agro-ecological principles, eco-functional intensification and the sufficiency principle [35]. 
However, the agro-ecological vision advocated by TP Organics strategically emulates the European Commission's dominant narrative of the KBBE in important respects. It emphasises the need for land use intensification (although the adverb used is 'eco-functional' instead of 'sustainable'), eco-efficiency and technological innovation and evades the question of economic growth [4]. This might alienate those parts of the agro-ecological perspective who are opposed to economic growth and the concept of eco-functional intensification, which might be viewed as being linked to a productivity oriented practice of organic farming that emulates many principles of conventional farming [36,37]. This alternative perspective within the broader movement of ecological or organic agriculture puts a stronger emphasis on a socio-political transformation and regards agro-ecology as a key strategy in the transition to a sustainable post-Capitalist, post-growth society [38-40]. In that sense, the narrative advocated by TP Organics constitutes only a part-albeit the most influential one-of the agro-ecological approach to the bioeconomy and may indeed stand in political-economic contradiction to other strands of the same imaginary that originate from civil society and farmers movements like Via Campesina and the Food Sovereignty movement [4,32].

In a recent draft European Bioeconomy Stakeholder Manifesto [41], which emerged as a result of the EC's plan to review its Bioeconomy Strategy, the vision portrayed by the stakeholders moves a step closer towards the agro-ecological vision. The stakeholders "regard the transition to a sustainable and circular bioeconomy as inevitable" (p. 3) and insist that a bioeconomy "should be sustainable in terms of people (jobs, inclusiveness), planet (biodiversity, ecological balance) and profit (resource efficiency, competitiveness) and it should contribute to reaching the UN Sustainable Development Goals" (p. 4). Although these goals and provisions are vague, they nevertheless move the narrative toward a more emphatic purpose of comprehensive sustainability that includes systemic changes and not only technological progress.

The three visions of the bioeconomy sketched so far (biotechnology, bio-resources and agro-ecology) roughly match the typology recently proposed by Bugge et al. [10]. However, they are organised along socio-technical strategies and thus do not adequately depict the different socio-political trajectories that a transition to a bioeconomy might entail. For example, the biotechnology vision and the bio-resource vision are conceptually entangled as both may rely on biotechnology and a large renewable resource base, while neither vision questions the overall direction of growth-based capitalist development. The agro-ecology vision, too, may lean more or less towards the application of advanced technologies and towards a growth-oriented vision of development or a sufficiency perspective. In analysing stakeholder positions and additional policy documents, we came to the conclusion that in order to show the possible techno-political bifurcations between different visions of a bioeconomy, we need to organise our typology along criteria that grasp the more fundamental questions of societal development entailed in a transition to a bioeconomy.

We therefore propose to locate different visions of the bioeconomy within a field that is constituted by two dimensions: one is the continuum between visions of agroecology and industrial biotechnology (the technological dimension), and the other is the continuum between visions of sufficiency and capitalist expansion (the political-economic dimension). The result is a field within which various empirical conceptions of the bioeconomy can be located and further hypothetical narratives can be devised (Figure 1). For practical purposes, we divide the field into four quadrants (A-D), each representing one of the four resulting paradigmatic combinations. These quadrants mark paradigmatic zones without clear-cut boundaries; rather, the entire field should be conceived as a techno-political option space in which various conceivable visions of the bioeconomy can be charted. The purpose of this option space is not only to systematise empirically existing narratives, but to show the 'empty spots', that is, areas where visions of a bioeconomy could be plausibly (and perhaps reasonably) constructed but where such narratives do not (yet) exist. We will show for example that sufficiency-based narratives granting a stronger role for state planning are virtually absent from the chart. The four quadrants of the techno-political option space are (A) Sustainable Capital; (B) Eco-Growth; (C) Eco-Retreat; and (D) Planned Transition. 


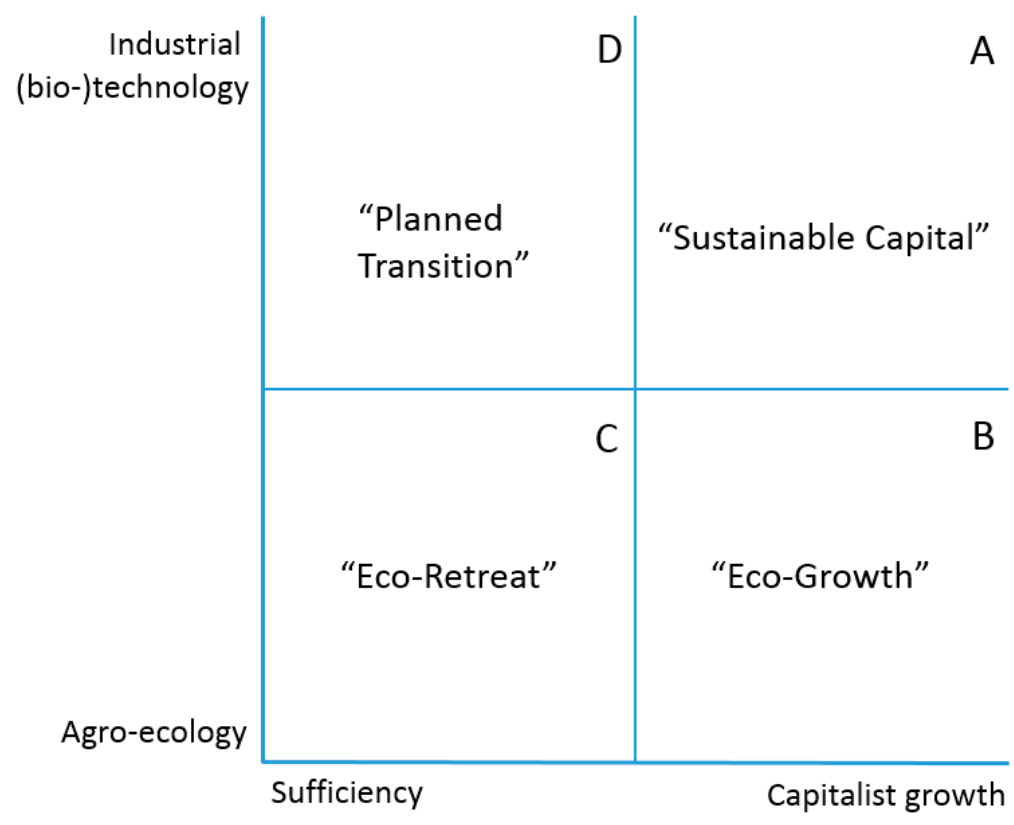

Figure 1. The techno-political option space for visions of a bioeconomy.

\section{A) "Sustainable Capital"}

This field is constituted by a belief in both, a technology-led transition to a (global) bioeconomy, and the continuation of capitalist growth. Technology plays a key role in all narratives located in this field. Some narratives focus on biotechnology as the key to a bioeconomy (like the OECD narrative discussed above), others are more neutral as to the types of technology applied, but emphasise the role of large scale industrial innovations like "biorefineries" or ascribe a key role to particular types of biomass, like cellulose or algae. While narratives in this field typically subscribe to a transition imperative, that is, to the historical task of transforming the fossil-fuelled economy into a bio-based economy due to climatic and resource challenges, they regard this transition as a source for new and sustained economic growth.

Following Birch et al. [29], we label this field "Sustainable Capital", as it is premised on the belief that in transiting to a renewable resource base, not only will capitalism become sustainable, but capital itself will become renewable, and thus sustainable. "In this vision, technological innovation unlocks the renewable, biophysical characteristics of nature itself through genetic and bio-molecular knowledge, thus enabling the continuing expansion and accumulation of capital“ ([29], p. 2899). Crucially, this narrative equates "renewable" with "sustainable" by adding "eco-efficient": an eco-efficient use of renewable resources promises a sustainable economy. Deep changes in the political-economic structures of society are not required, according to this strand of theory.

In line with this logic, narratives in this quadrant do not see a necessity to reduce overall consumption or to engage in a politics of sufficiency or voluntary frugality. For example, the global challenge of an increasing demand for meat and animal products is framed as an efficiency problem that can be met by a "sustainable intensification" of feed and livestock production and thus by increased output $[4,42,43]$. The bioeconomy represents an opportunity to increase global economic output further and to overcome the impending resource scarcity of the fossil-fuelled model of industrialism. The bioeconomy is generally presented as having no such constraints. The majority of official policy documents and state-led bioeconomy strategies is located in this quadrant.

\section{B) "Eco-Growth"}

Narratives in this field are characterised by a simultaneous belief in agro-ecological and organic farming practices on the one hand, and a growth-based capitalist economy on the other. The field is 
dominated by visions of organic entrepreneurship, agro-ecological innovation, small-scale farming practices and a regional rather than global focus. Although originally not couched in terms of the bioeconomy (as this term originated in quadrant $\mathrm{A}$ ), these visions were strategically adapted to the emerging narratives of a bioeconomy in order not to lose out against the dominant life science and agro-industries in the race for research funding and political influence $[4,12,44]$. Although some narratives in this field refer to "sufficiency" as a guiding principle, the meaning of the term is often restricted to the input-side of production and does not include the limitation of consumption or production. For example, TP Organics states that "[o]rganic agriculture [ ... ] puts into practice the sufficiency narrative. Compared to conventional agriculture, it is less reliant on external inputs" ([35], p. 12). The reduction of external inputs for a given output, however, can be better described in terms of "efficiency" than "sufficiency". Thus, the organic industry's allusion to sufficiency in this context seems to be more of a strategic-rhetoric nature than of a substantial kind, for sufficiency taken seriously necessarily involves reductions of per capita demand-it means producing and consuming less [45].

Narratives in this quadrant typically do not propose a global transition strategy or a comprehensive vision of an agro-ecological bioeconomy, but emphasise the important role that organic farming and agro-ecological practices can play in a post-fossil, bio-based economy [35]. Actors in this field include national and European organic farming associations and their think-tanks (like TP Organics) as well as organic enterprises and research institutions.

\section{C) "Eco-Retreat"}

We chose the label "Eco-Retreat" to capture all narratives that combine a commitment to ecological agriculture, forestry and fishery practices on the one hand, and a perspective of socio-economic sufficiency on the other. These narratives share a common vision for a comprehensive socio-ecological transition, which changes not only the resource base of the global economy, but the very principles of production, consumption and distribution, that is, the political-economic structures [46-48]. The clear priority of these narratives is for human activity to retreat within the biophysical boundaries of the planet in terms of a strong interpretation of sustainability [49-51]. A central tenet of narratives in this sector is that such a retreat is impossible with an expanding economic system: retreat therefore means an overall reduction of material consumption in industrialised countries and an equitable economic model that provides a "good life" for all $[52,53]$. Thus, these narratives typically involve strong claims for global economic and environmental justice $[52,54-56]$ and are oriented toward a global convergence of resource use and consumption patterns at a sustainable level, which requires a contraction of resource use patterns in industrial countries [57]. In terms of technology, narratives in this sector usually do not reject advanced technologies and eco-efficiency, but insist on small economic scales and democratic control over technologies and economic processes [40,58].

Narratives in this sector are usually not couched in terms of the "bioeconomy", since this terminology originated from the "Sustainable Capital" quadrant and is generally being regarded as hostile to "Eco-retreat" narratives. However, a post-fossil society based on the sufficiency principle and on an agro-ecological production paradigm will rely on biogenic resources for the production of food and, to some extent, materials and energy, and therefore be a bioeconomy as well, understood in a broader sense. Narratives in this sector can be regarded as the marginal counter-narratives to the dominant elitist visions of the bioeconomy. They are typically emerging from civil society movements like the degrowth movement [47,59,60], farmer's movements, the movement for food sovereignty [33], the environmental movement, green think tanks and critical academia.

\section{D) "Planned Transition"}

The fourth quadrant is characterised by the combination of a high (bio-)tech-vision with a sufficiency narrative. Empirically, there is little evidence of existing narratives in this sector, as the combination of large-scale high-tech and sufficiency contradicts both the dominant capitalist and the marginal degrowth-logics. Conceptually, however, this sector offers interesting additional options. 
The point of departure is the subscription to a sufficiency perspective that requires a reduction in material consumption at least in industrial countries and a global convergence of resource use patterns on an ecologically sustainable level. In contrast to visions in the "Eco-Retreat" sector, however, visions in this sector would respond to this challenge by applying advanced technologies on a large-scale industrial level. Visions may entail biorefineries converting sustainably sourced biomass into all sorts of products, eco-functional intensification of certain agricultural sectors, global trade in certain biogenic commodities and (perhaps) the use of biotechnologies and plant genetics. At the same time, these technologies would not be applied as a source for further growth and capital accumulation (as in "Sustainable Capital"), but within a politically coordinated strategy of a material contraction of the economy until human activity is back within the "safe operating space" of the planetary system [49].

The conceptual punchline of this quadrant is, of course, that such visions would have to be state-centred. As private industrial actors in a capitalist market have an intrinsic interest in capital accumulation and increasing output, they will not, by themselves, embark on a mission of voluntary sufficiency. Large-scale industrial structures for production and innovation, however, require respective organisational structures and financial resources. States would be the only conceivable entities able to provide the organisational environment and planning capacity necessary for this type of transition. Private corporations might still be key actors, but states would set the rules of the game and direct their overall activities. An additional conceptual difficulty in this sector is, of course, that modern states, too, depend on the income generated from a growing economy [61-63]. Nevertheless, in times of looming climatic collapse and ecological crisis, scenarios are conceivable, in which states derive legitimacy from planning, managing and carrying out a transition from a fossil-fuelled to a bio-based economy that provides a decent standard of living for all.

Table 1 provides a comparative summary of the policy papers selected for this overview (This overview of national and supranational policy papers is not intended to be comprehensive or systematic. We limited the selection of papers to OECD countries for practical purposes and for comparability, as the focus of this paper is the European rather than the global bioeconomy discourse. Future research could extend the scope of analysis and make use of emerging databases of policy papers worldwide (including bioresource-rich countries like Brazil, Malaysia and others) like the BioSTEP project of the EU (http:/ / www.bio-step.eu/).), while Figure 2 shows their position within the techno-political option space. In the top right corner of Figure 2, we can see a cluster consisting of the OECD, the USA and-with a small gap-Germany. The USA and OECD clearly focus their bioeconomy visions on the advancement of biotechnology as a new source of economic growth. The German position is similar but has a stronger emphasis on the bioeconomy's role in meeting global challenges like climate change, resource scarcity and food security. If taken seriously, this emphasis might weaken somewhat the vision's insistence on economic growth. The European Commission's official vision (2012) is couched in terms of "smart and green growth", thus combining the growth narrative with a commitment to tackling the grand societal challenges. The focus on biotechnology is no longer explicit. Interestingly, the narrative generated in a draft stakeholder manifesto (EU 2016) pushes the vision further towards comprehensive sustainability goals. 
Table 1. Overview of national and regional bioeconomy strategies.

\begin{tabular}{|c|c|c|c|c|}
\hline $\begin{array}{c}\text { Country/ } \\
\text { Organisation }\end{array}$ & Document Title & Vision/Motivation & Main Objectives & Main Strategies and Measures \\
\hline OECD (2009) & $\begin{array}{l}\text { The Bioeconomy to 2030: } \\
\text { Designing a Policy Agenda [19] }\end{array}$ & $\begin{array}{l}\text { To encourage the application of } \\
\text { biotechnology as a driver of } \\
\text { economic growth }\end{array}$ & $\begin{array}{l}\text { To help establish a global } \\
\text { bioeconomy, based on the } \\
\text { application of biotechnology }\end{array}$ & $\begin{array}{l}\text { Boost research; create international agreements to create } \\
\text { markets for sustainable biotech-products; create } \\
\text { international standards and regulatory systems for the use } \\
\text { of biotechnology in agriculture, health and industry }\end{array}$ \\
\hline USA (2012) & $\begin{array}{l}\text { National Bioeconomy } \\
\text { Blueprint [64] }\end{array}$ & $\begin{array}{l}\text { To advance economic activity } \\
\text { that is fuelled by research and } \\
\text { innovation in the biological } \\
\text { sciences; reduce dependence } \\
\text { on oil }\end{array}$ & $\begin{array}{l}\text { Expansion of emerging } \\
\text { bio-technologies }\end{array}$ & $\begin{array}{l}\text { Support R\&D activities; facilitate transition of } \\
\text { bioinventions from lab to market; reduce regulatory } \\
\text { barriers; update training programs; Identify and support } \\
\text { opportunities for the development of public-private } \\
\text { partnerships }\end{array}$ \\
\hline EU (2012) & $\begin{array}{l}\text { Innovating for Sustainable } \\
\text { Growth: A Bioeconomy for } \\
\text { Europe [2] }\end{array}$ & $\begin{array}{l}\text { To boost "smart and green } \\
\text { growth" in Europe; to tackle } \\
\text { societal challenges like food } \\
\text { security, natural resources } \\
\text { sustainability, climate change } \\
\text { mitigation }\end{array}$ & $\begin{array}{l}\text { Maintain and create economic } \\
\text { growth } \\
\text { and jobs, reduce fossil fuel } \\
\text { dependence; improve } \\
\text { sustainability of industries }\end{array}$ & $\begin{array}{l}\text { Investments in research, innovation and skills; reinforced } \\
\text { policy interaction and stakeholder engagement; } \\
\text { enhancement of markets and competitiveness in } \\
\text { bioeconomy. } \\
\text { Focus is on bio-based products and food-production } \\
\text { systems, not on biotechnology per se. }\end{array}$ \\
\hline EU (2016) & $\begin{array}{l}\text { European Bioeconomy } \\
\text { Stakeholders Manifesto [41] }\end{array}$ & $\begin{array}{l}\text { To facilitate an accelerated } \\
\text { transition from a fossil fuel } \\
\text { economy to a bioeconomy; to } \\
\text { make Europe a leader in a } \\
\text { sustainable bioeconomy }\end{array}$ & $\begin{array}{l}\text { To create a bioeconomy that is } \\
\text { sustainable in terms of 'people, } \\
\text { planet and profit' and that } \\
\text { contributes to reaching the UN } \\
\text { SDGs and the } 2{ }^{\circ} \mathrm{C} \text { climate goal }\end{array}$ & $\begin{array}{l}\text { Enhance connectivity throughout value chain; more } \\
\text { efficient use of biomass; close cycles of biomass and } \\
\text { construct circular economy; PPPs for biorefineries, etc.; } \\
\text { creating demand through public procurement }\end{array}$ \\
\hline Germany (2011) & $\begin{array}{l}\text { National Research Strategy } \\
\text { Bioeconomy } 2030 \text { [65] }\end{array}$ & $\begin{array}{l}\text { Vision of a sustainable biobased } \\
\text { economy by 2030; necessary to } \\
\text { meet global challenges like food } \\
\text { security and climate protection }\end{array}$ & $\begin{array}{l}\text { The optimal utilisation of the } \\
\text { chances created by } \\
\text { (bio)technological progress; to } \\
\text { achieve technology leadership }\end{array}$ & $\begin{array}{l}\text { Focus on research activity and innovation policy in the } \\
\text { field of biotechnology as a "major source of impetus" }\end{array}$ \\
\hline
\end{tabular}


Table 1. Cont.

\begin{tabular}{|c|c|c|c|c|}
\hline $\begin{array}{c}\text { Country/ } \\
\text { Organisation }\end{array}$ & Document Title & Vision/Motivation & Main Objectives & Main Strategies and Measures \\
\hline Sweden (2012) & $\begin{array}{l}\text { Swedish Research and } \\
\text { Innovation Strategy for a } \\
\text { Bio-based Economy [66] }\end{array}$ & $\begin{array}{l}\text { Transition from a fossil fuel } \\
\text { economy to a more } \\
\text { resource-efficient economy } \\
\text { based on renewable raw } \\
\text { materials that are produced } \\
\text { through the sustainable use of } \\
\text { ecosystem services from land } \\
\text { and water }\end{array}$ & $\begin{array}{l}\text { To reduce climate effects and } \\
\text { the use of fossil-based raw } \\
\text { materials; to optimise the value } \\
\text { and contribution of ecosystem } \\
\text { services to the economy }\end{array}$ & $\begin{array}{l}\text { Replacement of fossil-based with bio-based raw materials; } \\
\text { smarter products and smarter use of raw materials; } \\
\text { change in consumption habits and attitudes; reducing } \\
\text { consumption of goods without affecting consumer living } \\
\text { standards (e.g., through products with higher } \\
\text { quality/durability, etc.) }\end{array}$ \\
\hline Austria (2015) & $\begin{array}{l}\text { Status Quo Bioökonomie und } \\
\text { FTI-Aktivitäten in } \\
\text { Österreich-auf dem Weg zur } \\
\text { Bioökonomie-FTI-Strategie } \\
\text { ("Status Quo Bioeconomy and } \\
\text { R\&D-Activities in Austria: } \\
\text { towards a } \\
\text { Bioeconomy-R\&D-Strategy". } \\
\text { Translation by the authors.) [67] }\end{array}$ & $\begin{array}{l}\text { To strengthen the economy's } \\
\text { resilience and value added; to } \\
\text { support the gradual transition } \\
\text { from a fossil economy to a } \\
\text { sustainable economy; }\end{array}$ & $\begin{array}{l}\text { To strengthen the Circular } \\
\text { Economy; increase resource } \\
\text { efficiency and cascading use of } \\
\text { bioresources; technology } \\
\text { leadership in core industries } \\
\text { (e.g., wood-based products) }\end{array}$ & $\begin{array}{l}\text { Focus is on the material and integrated utilisation of } \\
\text { biogenic resources (mainly forestry and agro-based) for } \\
\text { non-food purposes; insist on "comprehensive } \\
\text { sustainability"; insist on public participation and } \\
\text { stakeholder involvement }\end{array}$ \\
\hline TP Organics (2014) & $\begin{array}{l}\text { Strategic Research and } \\
\text { Innovation } \\
\text { Agenda for Organic Food and } \\
\text { Farming [35] }\end{array}$ & $\begin{array}{l}\text { To contribute to "sustainable } \\
\text { food security" by strengthening } \\
\text { the "sufficiency narrative": } \\
\text { reducing external inputs in } \\
\text { production. }\end{array}$ & $\begin{array}{l}\text { To secure a strong role for } \\
\text { organic farming systems in the } \\
\text { European bioeconomy }\end{array}$ & $\begin{array}{l}\text { Eco-functional intensification; empowerment of rural } \\
\text { areas; food for health and well-being }\end{array}$ \\
\hline
\end{tabular}




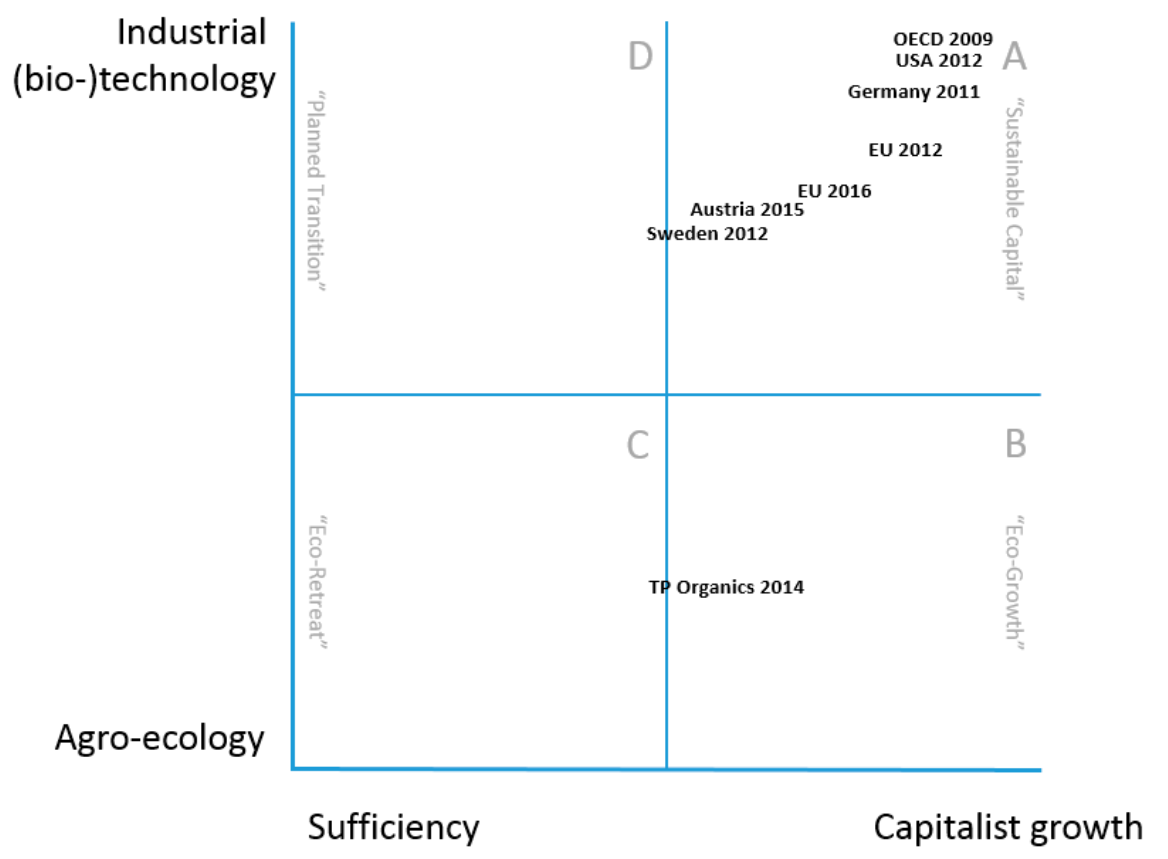

Figure 2. Position of selected policy papers within the techno-political option space.

The absence of economic growth as a core objective is even more pronounced in policy papers from Austria and Sweden. In the Austrian case, which will be analysed in more detail in the next section, the focus is on the "resilience" of the economy and on the creation of a closed value-added cycle (instead of a chain) based on the resource-efficient and cascading use of biomass. The role of technology is writ large, but it must be applied with the objective to reach the comprehensive sustainability of society. While the Austrian strategy paper does not mention the need for a sufficiency perspective or for reduced consumption levels, the Swedish strategy paper is unique in going a step further in this direction. Here, the vision is a transition from a fossil fuel economy to an economy that is based on the sustainable use of ecosystem services. A constitutive part of the Swedish vision is the need to reduce the consumption of goods without affecting consumer living standards. This provision makes the Swedish strategy the only one to contain a sufficiency perspective. However, concrete proposals for measures to achieve the goal of reduced consumption levels are quite limited: to make products of higher quality, such as in the case of clothes, or to produce goods with a longer shelf-life. Nevertheless, the Swedish strategy is still shy of tackling the "hot potato" issues of sufficiency, like reducing meat and dairy consumption or limiting private motorised transport.

The strategy paper by TP Organics, finally, is the only one located in the quadrant "Eco-Growth", however touching the boundary to "Eco-Retreat". This is due to the fact, that, while the think tank adheres to an agro-ecological perspective on technology (which includes high-tech innovation for eco-functional intensification), it has an ambiguous stance on the question of growth. On the one hand, it posits the organics industry as supporting the "sufficiency narrative", but on the other, it equates the meaning of sufficiency with "reduced external inputs", which is tantamount to efficiency, not sufficiency.

\section{Stakeholder Positions: The Case of AUSTRIA}

Policy papers typically represent condensed strategic discourses and action programmes that are based on compromises between institutions (ministries and agencies) and different elites (business, politics, some academia), and which do not necessarily reflect the positions, worldviews and opinions of a wide range of other stakeholders. We therefore additionally interviewed a total of 29 stakeholders in Austria from various relevant fields within the bioeconomy discourse, broadly conceived. The aim 
was to complete the picture and to carve out the different political, academic and ideological positions that make up the current techno-political option space for a transition to a bioeconomy in Austria.

It should be noted that some of the stakeholders interviewed are professionals in business associations and the public administration who might have had some influence in devising the Austrian bioeconomy strategy. Their views as stakeholders representing their respective professional association might differ significantly from the Austrian policy paper, however, since policy papers are typically based on institutional compromises and worded in a diplomatic tone. Our intention in including stakeholder positions in this survey was thus to represent a broad range of professional opinions from divergent societal sectors that can be contrasted and compared with official policy papers. To be sure, most stakeholders interviewed could be regarded as forming part of an elite (at least in terms of education), but the point of broadening the scope beyond business and policy elites is to include marginalised positions from civil society and critical academia as well.

Figure 3 shows the position of selected Austrian stakeholders on the bioeconomy within the techno-political option space. The stakeholders come from the realms of research, (environmental and agricultural) non-governmental organisations (NGOs), consulting, lobbying, several industrial branches related to the bioeconomy (pulp and paper, bioenergy, forestry) and public administration and were interviewed on a wide range of aspects of a bioeconomy. Their position within the techno-political option space was determined based on answers regarding assessments of the bioeconomy's relation to "smart and green growth", technological options to tackle the efficiency-challenge, the biogenic resource potential and risks regarding the widening of access to biogenic resources.

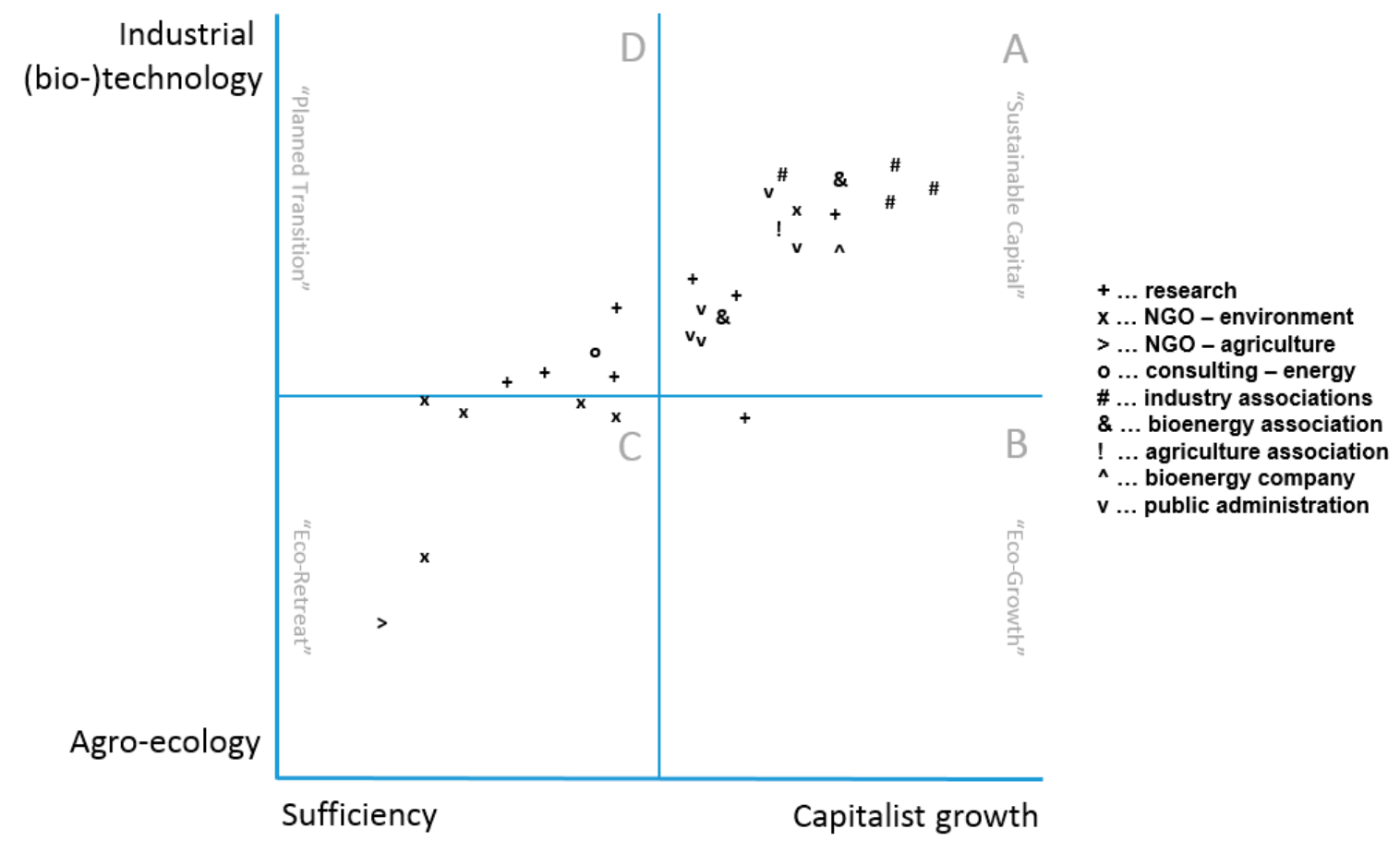

Figure 3. Position of Austrian stakeholders within the techno-political option space.

A first visual analysis reveals that most stakeholder positions are dispersed according to a "Milky Way"-like band stretching from the centre of "Sustainable Capital" (A) via the bottom right corner of "Planned Transition" (D) to the top of "Eco-Retreat" (C). The majority of positions (17 stakeholders or $59 \%$ ) is located in sector A, which appears to contain the mainstream vision. Perhaps not surprisingly, all stakeholders from business associations (processing industry, bioenergy and agricultural) as well as all public administration officials are located in this quadrant. However, only a minority of scientists $(37.5 \%)$ and only one NGO share this view. 
Sector D ( 5 stakeholders or $17 \%$ ) is populated by 4 (out of 8 ) scientists and an energy consultant. This shows that half the scientists interviewed tend to favour a planned transition toward a sufficiency-based bioeconomy that utilises (but is not solely predicated on) high technology. Sector C (6 stakeholders or $21 \%$ ), by contrast, is populated exclusively by NGOs (four environmental and one agricultural), the majority of which is bordering to quadrant $\mathrm{D}$. The agricultural NGO is the most radically sufficiency-oriented and technology-averse stakeholder. Sector B, finally, attracts only one stakeholder, who is a scientist. This might be counted as an indication that the combination of an agro-ecological vision with one of capitalist growth is somewhat counter-intuitive and may make sense mainly as a strategic narrative of market-oriented organic businesses as represented by TP Organics.

In a second step we can identify three distinct clusters within the "Milky Way" band. The largest one is located in the middle of sector A and comprises a third (11 out of 29) of the stakeholders. It is in good coherence with the European Commission's official strategy "Innovating for Sustainable Growth: A Bioeconomy for Europe" [2] and is dominated by business associations. We might call it the "industry cluster". Moving toward the centre of the graph, there is a smaller cluster that exhibits a more critical stance to the growth paradigm and to (bio-)technological progress. This cluster is dominated by public administration bodies and scientists. It is conspicuous that a majority of public administration stakeholders interviewed ( 3 out of 5 ) are located here. We may therefore call it the "public administration cluster". A third cluster (9 stakeholders) can be identified at the border area of sectors C and D and consists of scientists, NGOs and an energy consultant. This cluster, which may be termed the "civil society" cluster, is decidedly sceptical of economic growth as a societal vision and more or less neutral towards the utilisation of advanced technology. This can be interpreted in that technology is regarded as a means to the end of a bio-based sustainability transition rather than as an end in itself.

This clustering is revealing in that it shows that the representatives of the state seem to be positioned somewhere between the visions of industry (high growth, high tech) and civil society (state-sponsored and sufficiency-based transition to sustainability), with science supporting the visions of the state and civil society and some public officials supporting the industry vision.

Moving through the quadrants of the techno-political option space, we can now identify paradigmatic examples of the respective narratives they encapsulate. A typical position representing the narrative of "Sustainable Capital" is that of a representative of an industrial association. He believes that economic growth will continue to be essential and that growth related problems should be addressed through population politics. The bioeconomy is key to a future sustainable society, which will be based on hydrogen as a main source of industrial energy. The climate goals must not be reached by a strategy of economic degrowth or deindustrialisation, but through efficiency gains and an industrial transition. A representative of a business association sums up his position as thus: "At the end of the day it is about growth, about jobs, about European and Austrian added value. That is what is important to us".

One researcher in quadrant $\mathrm{D}$ (a professor of engineering, whose position is located at the upper right fringe of the civil society cluster) provides a good example of the narrative of a "Planned Transition": He believes that the transition to a bioeconomy is inevitable, but that the question is how it is organised. He does not believe in the bioeconomy to be an engine for "smart and green growth" ("the EU-speak is always a growth-speak"), but assumes that the industrialised world is entering an era of post-growth. He puts much hope in the concept of biorefineries, for which he sees great potential in Austria, especially as an extension of the pulp industry. This includes, for example, the production of hydrogen from biomass. The main challenge, according to him, is how to align the conservationist requirements of a bioeconomy (to secure biodiversity, soil fertility, water resources, the long-term availability of biogenic resources, etc.) with the economic requirements. He claims that the market is ill equipped to achieve this task. Instead, new mechanisms and "institutions for regional and participatory resource planning" are required. Furthermore, a radical ecological tax reform is 
necessary that puts the tax burden on resources and not on labour. These grave changes might result in a new economic system, and in a new institutional landscape.

The narrative of "Eco-Growth", in turn, is epitomised by its only proponent in this survey, a scientist working for an eco-business-oriented research institute. His central tenet is the belief in the concept of a "sustainable intensification of land use", while acknowledging the associated risks of biodiversity loss and soil degradation. According to him, sustainable intensification is a necessity for a bioeconomy. He is convinced that under certain, ambitious conditions (cascadic use of biomass, integrated biorefineries, sustainable intensification of land use, eco-efficiency, circular economy) the bioeconomy can be an economic growth engine. Overall, his narrative is both technoand eco-optimistic and based on the belief in the reconcilability of further economic expansion and an agro-ecological socio-technical paradigm.

The narrative of "Eco-Retreat" is perhaps best captured by the representative of the agricultural NGO. For her, the mainstream conception of the bioeconomy is "the latest strategy of industry, science and state institutions to gain power over the planet's biological resources". This includes the strategy of the sustainable intensification of land use, which is an attempt "to sugar-coat neoliberal, industry-driven strategies". She proposes to use the term agro-ecology instead of bioeconomy to denote a sustainable and equitable agro-economy that is based on biogenic resources. The strategy of further economic growth- "green" or otherwise-is declared to be in direct contradiction to the principles of agro-ecology. Although her approach involves technological innovation as an important element (especially in the sense of appropriate agricultural technologies to be applied in the global south), technology is not regarded as the key to an agro-ecological transition.

Our analysis of stakeholder positions shows that creating a typology of visions of the bioeconomy according to mainly technical criteria (i.e., biotechnology, bio-resources, agro-ecology) as in Bugge et al. [10] runs the risk of neglecting important—and, in our view, decisive—political dimensions that reveal the highly conflictive developmental trajectories associated with each vision. For example, Bugge et al.'s 'bio-ecological' vision does not show the techno-political cleavage between the visions of "Eco-Growth" and "Eco-Retreat", which both rely on the agro-ecological paradigm as a common socio-technical platform. Similarly, the techno-political differences between the visions "Sustainable Capital" and "Planned Transition" are massive, although both may rely on a socio-technical vision that entails the use of bio-technology and the reliance on bio-resources. Thus, by adding the dimension of "growth vs. sufficiency" to the socio-technical dimension, we arrive at a much more comprehensive option-space that reveals the techno-political cleavages between different visions of the bioeconomy.

\section{Modelling a Low-Carbon Bioeconomy for Austria-What Are the Options?}

Policy papers and stakeholder positions often do not explicitly consider given biophysical limitations due to area and productivity constraints. To further enrich the discussion of techno-political options for a transition to a sustainable bioeconomy, we therefore add the perspective of biophysical modelling, using the future bioeconomy of Austria as a case study. We present scenario results from a complex system model [68] that was generated for the research project "BioTransform.at" (Funded by the Austrian Climate Research Programme (ACRP), Project number B368631, 2014-2016.), of which this article also forms part. By locating the modelled scenarios within the techno-political option space, we can elucidate possible gaps between techno-political visions and biophysical options for Austria as a case study. The combination of discourse-analytical and biophysical modelling methods allows us to integrate the discursively constructed narratives in the techno-political option-space with a set of scenarios in the biophysical option-space of society.

The subject of investigation includes all relevant types of primary biomass, conversion processes (wood processing industries and advanced biomaterial production, food supply, animal husbandry, energy generation) and a complete representation of the energy sector. The geographical scope is Austria and the considered timeframe 2010-2050. The optimization target is to minimize greenhouse 
gas (GHG) emissions under given dynamic constraints (imposing limits on fuel switch rates, technology diffusion, crop rotation and many more), while economic aspects are disregarded.

The scenarios differ in terms of six influencing parameters relevant for the future supply potential and demand for domestic biomass. The developments of these parameters include trend extrapolations and business as usual assumptions on the one hand, and more speculative assumptions considered feasible in case of targeted policy intervention on the other. These exogenous parameters are developments in dietary habits, land use change, forest management, average crop yields, food losses and assumptions regarding bioenergy production from crop by-products (which represent a considerable unused potential for energy production).

In Scenario A ('Reference') the main historical trends concerning these parameters remain unchanged until 2050; i.e., no serious initiatives or policy intervention take place to reduce food losses, change dietary habits and to utilize crop by-products for energy; average crop yields continue to increase, albeit only moderately. In scenario B ('Intensive') higher agricultural yield increases and additional wood removals from small private forests are assumed, and crop by-products are assumed to be available as bioenergy source. Scenario C ('Alternative') is characterized by the aim to avoid intensification in biomass production. This is implemented as a more pronounced shift to healthy and no- or low-meat diets compared to Scenario A and B, reduced land use change after 2020, reduced food losses, constant average crop yields and forest management with longer rotation periods.

The scenarios demonstrate that a transformation to a low-carbon bioeconomy until 2050 is technically feasible without increasing net biomass imports to Austria-but only if energy consumption is reduced significantly, other renewable energy sources are employed intensively and biomass and bioenergy are utilized in an efficient way. The scenarios also illustrate that-with regard to biomass supply and consumption—quite different pathways are possible. Technically, this has been achieved by exogenously assuming different future developments in dietary habits, land use change, forest management, average crop yields, food losses and bioenergy from crop residues. GHG reductions of at least $80 \%$ compared to Austria's Kyoto baseline are achieved in an "intensive" as well as an "alternative" scenario with regard to these parameters: In Scenario B ("Intensive") large additional amounts of biomass are mobilized. Total domestic biomass consumption increases by more than $30 \%$ from 2010 to 2050, mainly due to higher agricultural yields and an enhanced use of crop residues for energy and material uses. In Scenario C ("Alternative") total biomass consumption increases by only $12 \%$, but due to a greater shift towards no- and low-meat diets, lower food losses and reduced loss of agricultural land, primary biomass can be diverted to bioenergy and biomaterials production. GHG emissions related to food supply (or rather animal husbandry) are also clearly lower in C than in B.

Where do these scenarios figure, then, in terms of the techno-political option space discussed in this paper (Figure 4)? First, all three scenarios assume a reduction of overall energy consumption of about $40 \%$, based on the "WAM plus scenario" (With Additional Measures plus) developed in the context of Austria's GHG reporting obligation [69]. These reductions are assumed to be possible only with sufficiency measures in private transport and consumer goods. A change in consumption patterns towards a "sharing economy", which implies a marked reduction in private ownership of long-lived consumer goods, as well as a penalisation of planned obsolescence are mentioned in the storyline underpinning the WAM plus scenario. Another crucial aspect is a significant shift in the modal split of transportation. All this amounts to a quite substantial politics of sufficiency for all scenarios, which will require rather courageous political planning, steering and intervention.

Where are the differences, then? In contrast to reference scenario A, both scenarios B and C reach the stipulated GHG reduction objective of $80 \%$, which is a necessary (but not sufficient) condition for being considered "sustainable". This objective, however, is achieved by contrasting measures, corresponding to different techno-political narratives underlying the scenarios: Scenario B is based on the vision of a further intensification of land use, i.e., continued linear increases of agricultural yields through (bio-)technological progress, increased industrial inputs (i.e., synthetic fertilizers and 
pesticides) and an increase of wood harvests. Scenario C, by contrast, is based on a vision of less intensive farming practices, with agricultural yields remaining on current levels and a less intensive use of forests. The lower productivity of land in scenario $C$ is compensated by a pronounced shift to a vegetarian or low-meat diet, which is a stark commitment to a socio-political sufficiency perspective.

In sum, the model results show, first, that all viable options for a low-carbon bioeconomy in Austria are necessarily tied to a rather substantial politics of sufficiency, without which the limited biogenic resources will not suffice to keep a bioeconomy going. Second, scenarios B and C illustrate that only an even stronger focus on sufficiency, here in particular with regard to food consumption, allows for a more extensive/agro-ecological land use with lower land productivities. The structural (socio-economic and political) implications for society are not yet fully understood, but may be far-reaching. Figure 4 shows the resulting location of the model scenarios in the techno-political option space:

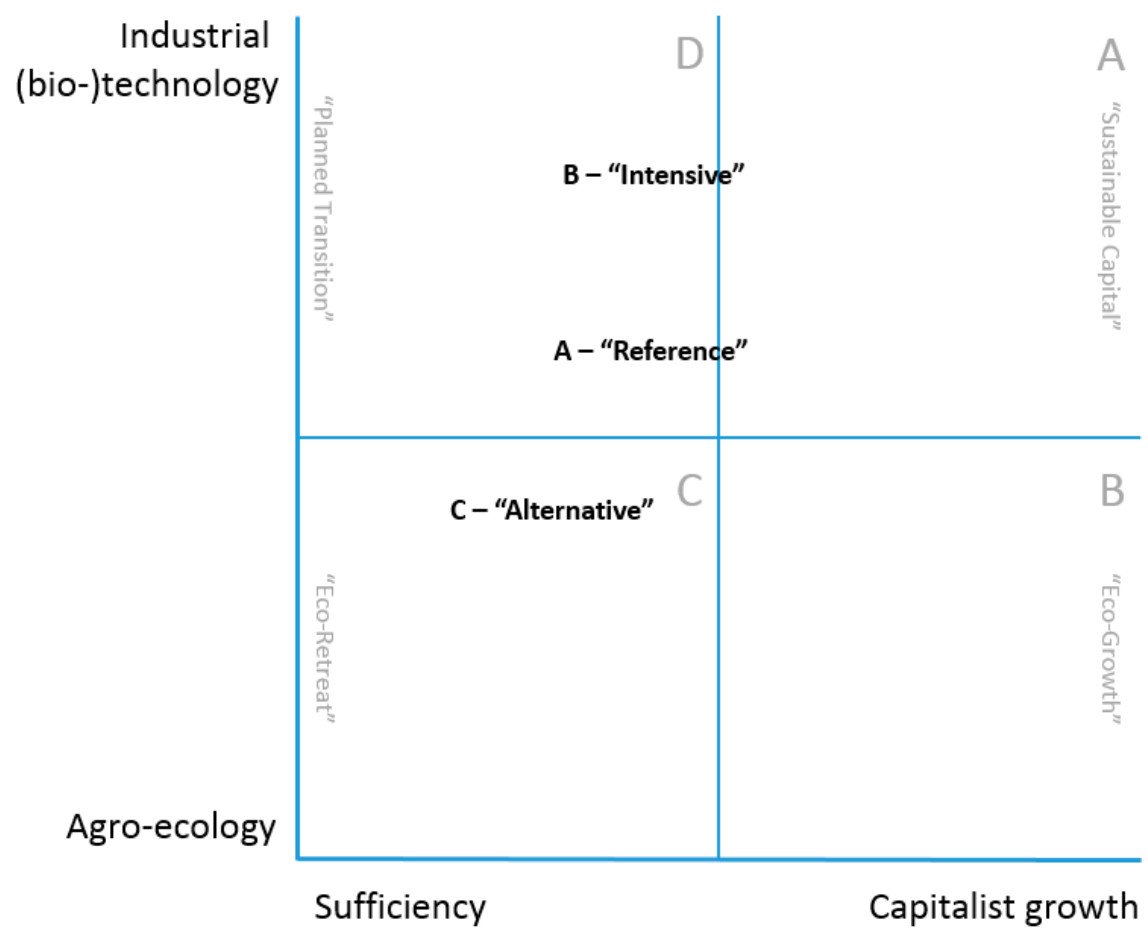

Figure 4. Biophysical model scenarios in the techno-political option space.

None of the scenarios is located in the politically favoured quadrant "Sustainable Capital" (although A and B are touching the border), but two of them are located in the quadrant "Planned Transition", of which only one reaches the GHG emission targets. The third scenario is located in the quadrant "Eco-Retreat". This is remarkable as it shows a rather significant gap between the politically salient and elite-driven visions of "Sustainable Capital" and the available biophysical options. It also hints at a gap between different state-sponsored political strategies that rely on different and potentially mutually exclusive buzzwords like "green growth" and "sharing economy". Identifying and understanding the different socio-economic and political trajectories that are implied in such diverging visions, as well as their concrete policy implications, remains an important task not only for social scientists.

\section{Discussion and Concluding Remarks}

"Energy transformations", Barry et al. state, "are political struggles, not simply technological, market-driven policy decisions" ([70], p. 3). Indeed, they continue, "political contestation, struggle and 
antagonism are central to understanding and analysing, as well as effecting low carbon socio-energy transformations" ([70], p. 3).

These words should caution us not to take the transformation to a bioeconomy too lightly and not to regard it as a pre-defined techno-scientific project that simply changes the way we produce our goods and heat our homes. A transition to a bioeconomy is more than an energy transformation: it is a wholesale resource transformation that will change-in the last instance- the very nature of societies and the face of the planet. A transition is inevitable, but the question is to which bioeconomy that supports which type of society. What will be the political-economic structure of the bioeconomy? What will be the role of the state? Which technologies will be used and on whose behalf? Who will have access to which bio-resources? Who will be exceluded? Whatever the answers to these questions, there will be winners and losers in the process, and there will be social antagonisms within and between nations about the objectives, principles, moral standards, economic structures and material boundaries of the new economic model.

Our analysis of diverging visions of a bioeconomy showed that there is a considerable gap between policy papers and visions supported by various stakeholders, including scientists and civil servants. What is more, there is a gap, at least in the case of Austria analysed in this paper, between the official strategies and the biophysical option space identified in a complex system model. The resulting map of positions is presented in Figure 5:

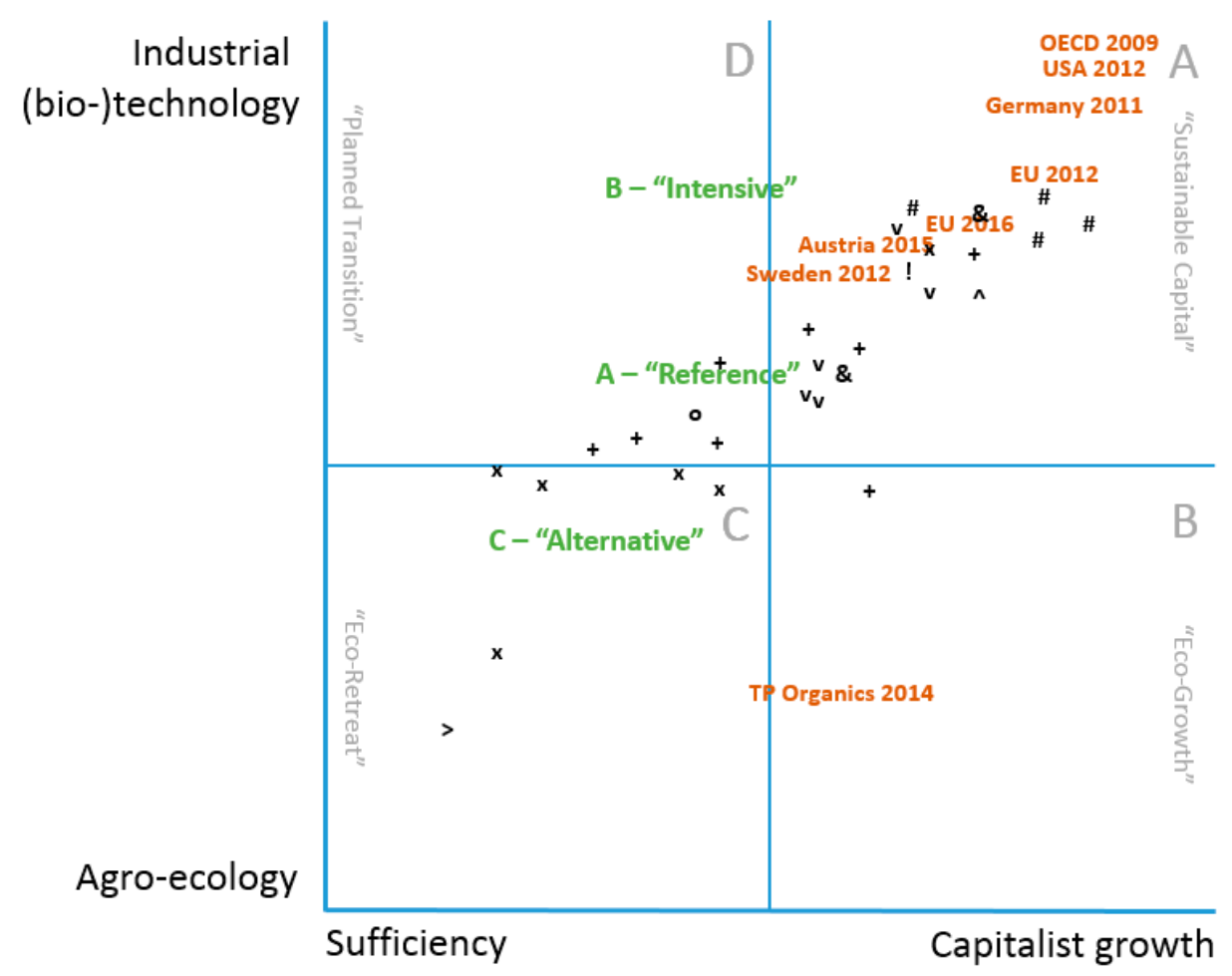

Figure 5. Synopsis of position in the techno-political option space.

This diagram was created combining three different methods of extracting and interpreting techno-political narratives: the hermeneutic interpretation of policy documents; the coding and interpretation of stakeholder interviews and the interpretation of scenarios in a biophysical model. We thus combined hermeneutic methods used in science- and technology studies (STS) with biophysical methods used in sustainability sciences. The result is an illuminative heuristic, which allows us to compare and contrast different visions of the bioeconomy and to highlight conspicuous gaps and inconsistencies as well as clusters and continuities. The results should be taken with some diligent caution, however. The mix of methods applied here requires a level of interpretation that cannot 
easily be measured against quantifiable criteria. Different scholars might have arrived at slightly different interpretations of the respective positions, resulting in a slightly different mapping of the techno-political option space. Despite the necessary interpretive latitude, we believe that the results presented here are robust and provide an interesting point of departure for further debates on divergent visions of the bioeconomy.

Perhaps the most striking result of our analysis is that all official policy papers are located in the "Sustainable Capital" quadrant that combines a vision of biotechnological progress with a narrative of green growth. Austrian stakeholders, even the representatives of business associations, are more moderate in their views on economic growth and biotechnology than some of the policy papers defining the mainstream vision of the bioeconomy. What is more, several stakeholder positions, mostly academic, as well as two out of three biophysical scenarios, are located in the "Planned Transition" quadrant, which combines a vision of technological progress with a narrative of sufficiency that requires much more coordinated and programmatic action by the state. Although the strategy papers of Austria and Sweden are relatively close to that quadrant, they still do not embrace the necessity of stringent sufficiency measures that is suggested by biophysical model results. The vision of "Eco-Growth" is hardly popular in Austria and is, more importantly, not considered a viable scenario in the biophysical modelling exercise [68]. Nevertheless, it has been identified as one of three visions of the bioeconomy in academic literature by Bugge et al. [10]. This mismatch between academic (and policy) discourse on the one hand and biophysical options and stakeholder visions on the other requires further scrutiny. Lastly, the vision of "Eco-retreat", which is popular with NGOs, does not figure in the academic discourse on the bioeconomy, although it is more plausible in biophysical terms than the vision of "Sustainable Capital".

It seems that official visions of the emerging bioeconomy are following a particular purpose or agenda that has not yet entered into serious conversation with deviant positions in the scientific community and civil society. The concept of the bioeconomy has been termed an "elite master narrative" by Birch et al. [29] and our own analysis tends to support this view. Efforts by the European Commission to enter into a meaningful process of stakeholder consultations have started to change this picture to some extent, as the marked shift between the EC's own strategy paper of 2012 [2] and the draft EU stakeholder manifesto of 2016 [41] demonstrates. This process shows that a meaningful conversation with other than industrial perspectives leads to substantial shifts between the imaginaries on which narratives of the envisaged bioeconomy are based.

A detailed discussion of what these shifts might entail for the roles of the state, business, academia and civil society is beyond the scope of this paper. However, a few tentative conclusions can be drawn:

- If narratives within the quadrant of "Sustainable Capital" are biophysically implausible, then relevant bodies of the state should start thinking about shifting their own conception of the bioeconomy towards a more sufficiency- and planning-oriented narrative. This would create tensions within the state and between state and business actors, which would need to be addressed both scientifically and politically. It is indeed alarming that all policy papers examined in this paper are located in the "Sustainable Capital" quadrant.

- The role of the state in a transition to a bioeconomy might need to be stronger than most policy papers and industry-oriented stakeholder positions suggest. This is because a transition to a (sustainable) bioeconomy may to a much larger than presently conceded extent have to be planned rather than left to the market. The role of academia-who seems to reflect this problematic in their stakeholder positions-should be to explore this question further and to expose the cleavage between the biophysical option-space and the dominant policy narratives.

- Civil society actors might capitalise on the apparent discrepancy between official visions of the bioeconomy on the one hand and biophysical reality and some academic positions on the other. They might feel motivated by this discrepancy to devise their own alternative visions and to push both policy-makers and business actors to re-evaluate their respective visions. 
If this conversation is to be continued and the generation of visions and imaginaries of the bioeconomy not to be left to narrowly-defined elites, then processes of serious stakeholder engagement and citizen participation need to be set up [71]. If the transition to a bioeconomy is to be democratic, it will have to start with openly debating not only the means but also the aims, contours, limits, moral standards and principles of that future economic model.

Acknowledgments: This paper is prepared as part of the project "BioTransform.at-Using domestic land and biomass resources to facilitate a transformation towards a low-carbon society in Austria", supported by the Austrian Climate and Energy Fund within the Austrian Climate Research Programme (project number B368631). In addition, funding from the Austrian Science Fund FWF (project "greenhouse gas effects of global land-use competition", P 29130) and the Austrian Academy of Sciences ÖAW (project "zero emissions from agriculture, forestry and other land use in the Eisenwurzen and beyond") is gratefully acknowledged.

Author Contributions: All authors contributed substantially to the conception of the paper. Daniel Hausknost was responsible for conceptual work, literature review and most of the writing; Ernst Schriefl carried out the stakeholder interviews and their analysis; Christian Lauk was involved in conceptual work, literature review and biophysical modelling and Gerald Kalt was responsible for the biophysical model on which Section 4 of the paper is based.

Conflicts of Interest: The authors declare no conflict of interest.

\section{References}

1. European Commission (EC). A Roadmap for Moving to a Competitive Low Carbon Economy in 2050; COM (2011) 112; Office for Official Publications of the European Communities: Brussels, Belgium, 2011.

2. European Commission (EC). Innovating for Sustainable Growth: A Bioeconomy for Europe; COM (2012) 60; Office for Official Publications of the European Communities: Brussels, Belgium, 2012.

3. Schmid, O.; Padel, S.; Levidow, L. The Bio-Economy Concept and Knowledge Base in a Public Goods and Farmer Perspective. Bio-Based Appl. Econ. 2012, 1, 47-63.

4. Levidow, L.; Birch, K.; Papaioannou, T. EU agri-innovation policy: Two contending visions of the bio-economy. Crit. Policy Stud. 2012, 6, 40-65. [CrossRef]

5. Hackfort, S.K. Bioökonomie. In Wörterbuch Klimadebatte; Transcript: Bielefeld, Germany, 2016; pp. 37-42.

6. Hecht, G. The Radiance of France: Nuclear Power and National Identity after World War II; Inside Technology; MIT Press: Cambridge, MA, USA, 2009.

7. Felt, U.; Wynne, B.; Callon, M. Taking European Knowledge Society Seriously: Report of the Expert Group on Science and Governance to the Science, Economy and Society Directorate, Directorate-General for Research, European Commission; European Commission, Ed.; EUR 22700; European Commission: Luxembourg, 2007.

8. Fairclough, N. Critical Discourse Analysis: The Critical Study of Language, 2nd ed.; Routledge: London, UK, 2013.

9. Birch, K.; Tyfield, D. Theorizing the Bioeconomy: Biovalue, Biocapital, Bioeconomics or ... What? Sci. Technol. Hum. Values 2013, 38, 299-327. [CrossRef]

10. Bugge, M.; Hansen, T.; Klitkou, A. What Is the Bioeconomy? A Review of the Literature. Sustainability 2016, 8, 691. [CrossRef]

11. Hagemann, N.; Gawel, E.; Purkus, A.; Pannicke, N.; Hauck, J. Possible Futures towards a Wood-Based Bioeconomy: A Scenario Analysis for Germany. Sustainability 2016, 8, 98. [CrossRef]

12. Levidow, L.; Birch, K.; Papaioannou, T. Divergent Paradigms of European Agro-Food Innovation: The Knowledge-Based Bio-Economy (KBBE) as an R\&D Agenda. Sci. Technol. Hum. Values 2013, 38, 94-125.

13. Pfau, S.; Hagens, J.; Dankbaar, B.; Smits, A. Visions of Sustainability in Bioeconomy Research. Sustainability 2014, 6, 1222-1249. [CrossRef]

14. Richardson, B. From a fossil-fuel to a biobased economy: The politics of industrial biotechnology. Environ. Plan. C Gov. Policy 2012, 30, 282-296. [CrossRef]

15. Staffas, L.; Gustavsson, M.; McCormick, K. Strategies and Policies for the Bioeconomy and Bio-Based Economy: An Analysis of Official National Approaches. Sustainability 2013, 5, 2751-2769. [CrossRef]

16. Scordato, L.; Bugge, M.; Fevolden, A. Directionality across Diversity: Governing Contending Policy Rationales in the Transition towards the Bioeconomy. Sustainability 2017, 9, 206. [CrossRef]

17. Enriquez-Cabot, J. Genomics and the World's Economy. Sci. Mag. 1998, 281, 925-926. 
18. McCormick, K.; Kautto, N. The Bioeconomy in Europe: An Overview. Sustainability 2013, 5, $2589-2608$. [CrossRef]

19. Organisation for Economic Cooperation and Development (OECD). The Bioeconomy to 2030: Designing a Policy Agenda; OECD International Futures Project; OECD Publishing: Paris, France, 2009.

20. European Commission; Directorate-General for Research and Innovation. Bio-Based Economy in Europe: State of Play and Future Potential-Part 2; EUR-OP: Luxembourg, 2011.

21. European Parliament (EP). Lisbon European Council 23 and 24 March 2000: Presidency Conclusions; European Parliament: Brussels, Belgium, 2000.

22. European Commission (EC). Life Sciences and Biotechnology-A Strategy for Europe: Communication from the Commission to the European Parliament, the Council, the Economic and Social Committee and the Committee of the Regions; COM (2002) 27; Office for Official Publications of the European Communities: Brussels, Belgium, 2002.

23. European Commission (EC). New Perspectives on the Knowledge-Based Bio-Economy: Transforming Life Sciences Knowledge into New, Sustainable, Eco-Efficient and Competitive Products; Office for Official Publications of the European Communities: Brussels, Belgium, 2005.

24. Stern, N.H. The Economics of Climate Change: The Stern Review; Cabinet Office, HM Treasury, Ed.; Cambridge University Press: Cambridge, UK; New York, NY, USA, 2007.

25. IPCC. Climate Change 2007: Synthesis Report; Contribution of Working Groups I, II and III to the Fourth Assessment Report of the Intergovernmental Panel on Climate Change; IPCC, Ed.; IPCC: Geneva, Switzerland, 2007.

26. European Commission (EC). 2020 by 2020: Europe's Climate Change Opportunity; COM (2008) 30; Office for Official Publications of the European Communities: Brussels, Belgium, 2008.

27. European Commission (EC). EUROPE 2020: A Strategy for Smart, Sustainable and Inclusive Growth; COM (2010) 2020; Office for Official Publications of the European Communities: Brussels, Belgium, 2010.

28. European Commission (EC). A Resource-Efficient Europe-Flagship Initiative under the Europe 2020 Strategy; COM (2011) 21; Office for Official Publications of the European Communities: Brussels, Belgium, 2011.

29. Birch, K.; Levidow, L.; Papaioannou, T. Sustainable Capital? The Neoliberalization of Nature and Knowledge in the European "Knowledge-based Bio-economy". Sustainability 2010, 2, 2898-2918.

30. Organisation for Economic Cooperation and Development (OECD). The Bioeconomy to 2030: Designing a Policy Agenda. Scoping Document; OECD International Futures Project; OECD Publishing: Paris, France; New Milford, CT, USA, 2006.

31. Action for Solidarity Environment Equality and Diversity (A SEED) European Food Declaration 2010. Available online: http:/ / aseed.net/en/european-food-declaration-launched/ (accessed on 29 July 2016).

32. Nyeleni Europe European Food Sovereignty Declaration 2011. Available online: http:/ / nyelenieurope.net/ publications/nyeleni-europe-declaration-2011 (accessed on 29 July 2016).

33. Nyéléni Declaration Declaration of Nyéléni 2007. Available online: http://nyelenieurope.net/sites/default/ files/2016-06/DeclNyeleni-en_0.pdf (accessed on 29 July 2016).

34. IFOAM-EU Group. Technology Platform for Sustainable Organic and High Welfare Food and Farming Systems, Proposal to the European Commission for a Specific Support Action (SSA). International Federation of Organic Agriculture Movements (IFOAM); IFOAM-EU Group: Brussels, Belgium, 2006.

35. European Technology Platform for Organic Food and Farming Research (TP Organics). Strategic Research and Innovation Agenda for Organic Food and Farming 2014; TP Organics: Brussels, Belgium, 2014.

36. Buck, D.; Getz, C.; Guthman, J. From Farm to Table: The Organic Vegetable Commodity Chain of Northern California. Sociol. Rural. 1997, 37, 3-20. [CrossRef]

37. De Wit, J.; Verhoog, H. Organic values and the conventionalization of organic agriculture. NJAS Wagening J. Life Sci. 2007, 54, 449-462. [CrossRef]

38. Infante Amate, J.; González de Molina, M. "Sustainable de-growth" in agriculture and food: An agro-ecological perspective on Spain's agri-food system (year 2000). J. Clean. Prod. 2013, 38, 27-35. [CrossRef]

39. De Molina Navarro, M.G. Agroecology and Politics: On the Importance of Public Policies in Europe. In Law and Agroecology: A Transdisciplinary Dialogue; Monteduro, M., Buongiorno, P., Di Benedetto, S., Isoni, A., Eds.; Springer: Berlin/Heidelberg, Germany, 2015; pp. 395-410.

40. Boillat, S.; Gerber, J.-F.; Funes-Monzote, F.R. What economic democracy for degrowth? Some comments on the contribution of socialist models and Cuban agroecology. Futures 2012, 44, 600-607. [CrossRef] 
41. The Fourth BioEconomy Stakeholders' Conference. European Bioeconomy Stakeholders Manifesto. Building blocks. Draft version; Dutch Ministry of Economic Affairs: Utrecht, The Netherlands, 2016.

42. Royal Society (Great Britain). Reaping the Benefits: Science and the Sustainable Intensification of Global Agriculture; The Royal Society: London, UK, 2009.

43. Tilman, D.; Balzer, C.; Hill, J.; Befort, B.L. Global food demand and the sustainable intensification of agriculture. Proc. Natl. Acad. Sci. USA 2011, 108, 20260-20264. [CrossRef] [PubMed]

44. Halberg, N.; Panneerselvam, P.; Treyer, S. Eco-functional Intensification and Food Security: Synergy or Compromise? Sustain. Agric. Res. 2015, 4, 126. [CrossRef]

45. Princen, T. The Logic of Sufficiency; MIT Press: Cambridge, MA, USA, 2005.

46. Haberl, H.; Fischer-Kowalski, M.; Krausmann, F.; Martinez-Alier, J.; Winiwarter, V. A socio-metabolic transition towards sustainability? Challenges for another Great Transformation. Sustain. Dev. 2011, 19, 1-14. [CrossRef]

47. Schneider, F.; Kallis, G.; Martinez-Alier, J. Crisis or opportunity? Economic degrowth for social equity and ecological sustainability. Introduction to this special issue. J. Clean. Prod. 2010, 18, 511-518. [CrossRef]

48. Brand, U.; Brunnengräber, A.; Omann, I.; Hollaender, K.; Driessen, P.; Hausknost, D.; Haberl, H.; Læssøe, J.; Andresen, S.; Schneidewind, U.; et al. Debating transformation in multiple crises. In World Social Science Report 2013; OECD Publishing: Paris, France, 2013; pp. 480-484.

49. Rockström, J.; Steffen, W.; Noone, K.; Persson, Å.; Chapin, F.S.; Lambin, E.F.; Lenton, T.M.; Scheffer, M.; Folke, C.; Schellnhuber, H.J.; et al. A safe operating space for humanity. Nature 2009, 461, 472-475. [CrossRef] [PubMed]

50. Neumayer, E. Weak versus Strong Sustainability: Exploring the Limits of Two Opposing Paradigms, 2nd ed.; Edward Elgar: Cheltenham, UK; Northampton, MA, USA, 2003.

51. Daly, H.E. Economics in a Full World. Sci. Am. 2005, 293, 100-107. [CrossRef] [PubMed]

52. Muraca, B. Towards a fair degrowth-society: Justice and the right to a "good life" beyond growth. Futures 2012, 44, 535-545. [CrossRef]

53. Gudynas, E. Buen Vivir: Today's tomorrow. Development 2011, 54, 441-447. [CrossRef]

54. Schlosberg, D. Theorising environmental justice: The expanding sphere of a discourse. Environ. Politics 2013, 22, 37-55. [CrossRef]

55. Martínez-Alier, J. Environmental Justice and Economic Degrowth: An Alliance between Two Movements. Capital. Nat. Social. 2012, 23, 51-73. [CrossRef]

56. Forsyth, T. Climate justice is not just ice. Geoforum 2014, 54, 230-232. [CrossRef]

57. Fischer-Kowalski, M.; Swilling, M.; von Weizsäcker, E.U. Decoupling Natural Resource Use and Environmental Impacts from Economic Growth. A Report of the Working Group on Decoupling to the International Resource Panel; UNEP: Nairobi, Kenya, 2011.

58. Johanisova, N.; Wolf, S. Economic democracy: A path for the future? Futures 2012, 44, 562-570. [CrossRef]

59. Latouche, S. Degrowth. J. Clean. Prod. 2010, 18, 519-522. [CrossRef]

60. Research \& Degrowth. Degrowth Declaration of the Paris 2008 conference. J. Clean. Prod. 2010, 18, 523-524.

61. Lipset, S.M. Some Social Requisites of Democracy: Economic Development and Political Legitimacy. Am. Political Sci. Rev. 1959, 53, 69-105. [CrossRef]

62. Habermas, J. Legitimation Crisis; Polity Press: Cambridge, UK, 1988.

63. Bailey, D. Rethinking the Fiscal and Monetary Political Economy of the Green State; SPERI Paper No. 37; Sheffield Political Economy Research Institute (SPERI): Sheffield, UK, 2017.

64. The White House. National Bioeconomy Blueprint; The White House: Washington, DC, USA, 2012.

65. BMBF. National Research Strategy BioEconomy 2030: Our Route towards a Biobased Economy; Bundesministerium für Bildung und Forschung (BMBF): Berlin, Germany, 2011.

66. FORMAS. Swedish Research and Innovation Strategy for a Bio-Based Economy; Forskningsrådet för miljö, areella näringar och samhällsbyggande, Formas: Stockholm, Swedon, 2012.

67. FTI-AG2: Klimawandel und Ressourcenknappheit. Status Quo Bioökonomie und FTI-Aktivitäten in Österreich - auf dem Weg zur Bioökonomie-FTI-Strategie. Ein Beitrag zur Bioökonomie-Entwicklung in Österreich; FTI-AG2: Klimawandel und Ressourcenknappheit, Ed.; Arbeitspapier der FTI-AG2; Ministerium für ein lebenswertes Österreich: Wien, Austria, 2015. 
68. Kalt, G.; Baumann, M.; Lauk, C.; Kastner, T.; Kranzl, L.; Schipfer, F.; Lexer, M.; Rammer, W.; Schaumberger, A.; Schriefl, E. Transformation scenarios towards a low-carbon bioeconomy in Austria. Energy Strategy Rev. 2016, 13-14, 125-133. [CrossRef]

69. Umweltbundesamt. Energiewirtschaftliche Szenarien im Hinblick auf die Klimaziele 2030 und Szenario WAM Plus-Synthesebericht 2015; Umweltbundesamt: Wien, Austria, 2015.

70. Barry, J.; Hume, T.; Ellis, G.; Curry, R. Low Carbon Transitions and Post-Fossil Fuel Energy Transformations as Political Struggles: Analysing and Overcoming “Carbon Lock-in”. In Energy \& Environmental Transformations in a Globalizing World: An Interdisciplinary Dialogue; Nomiki Bibliothiki: Athens, Greece, 2015; pp. 3-23.

71. Albrecht, S.; Gottschick, M.; Schorling, M.; Stirn, S. Bioökonomie am Scheideweg. Industrialisierung von Biomasse oder nachhaltige Produktion? GAIA 2012, 21, 33-37. [CrossRef]

(C) 2017 by the authors. Licensee MDPI, Basel, Switzerland. This article is an open access article distributed under the terms and conditions of the Creative Commons Attribution (CC BY) license (http://creativecommons.org/licenses/by/4.0/). 